Vol. 1, No. 1, 79-85

\title{
GENDER DIFFERENCES IN ANXIETY: AFTER 4 MONTHS OF THE COVID-19 PANDEMIC IN LAMPUNG
}

\author{
Lolita Sary 1 , Octa Reni $\mathbf{S}^{2}$, Vida Wira Utami ${ }^{3}$, \\ Erna Listyaningsih ${ }^{4}$, Achmad Farich 5 , Dessy Hermawan 6 , Helfi Agustin 7 \\ 1,2,3,4,5,6 Lecturer at Universitas Malahayati, Lampung \\ ${ }^{7}$ Lecturer at Universitas Ahmad Dahlan, Yogyakarta \\ Correspondence: ores.survive@gmail.com
}

\begin{abstract}
Facing the Covid-19 pandemic with a high death rate in almost many countries has caused public anxiety. Lampung Province, 4 months after the State of Indonesia declared the Covid19 pandemic, had 1,203 deaths, 543 suspects and 21,878 confirmed cases. Gender is one of the factors that can affect anxiety in dealing with the Covid-19 pandemic. The purpose of the study was to determine the difference in anxiety between men and women after 4 months of the covid19 pandemic in Lampung. Quantitative research with a cross-check sectional approach, sample was obtained by accidental sampling by filling out an online questionnaire for the Lampung community aged $\geq 17$ years with a total of 102 people. The sample consisted of 31 men and 71 women. The analysis using independent sample $t$ test with Mann Whitney Non- Parametric. The result showed that there was no difference in anxiety between men and women after 4 months of the Covid19 pandemic in Lampung (Asymp. Sig. (2-tailed) $=$ $0.626)$.
\end{abstract}

Keywords: Covid19, Anxiety, Men, Women

\section{Introduction}

In the difficult conditions of the Covid-19 pandemic, people tend to experience anxiety. Anxiety is a worry about things that are out of control in the future. Since March 11, 2020, WHO has declared a pandemic situation globally due to the outbreak of Corona Virus Disease (Covid-19). On March 16, it was recorded that 213 countries had contracted Covid-19, and 308,810 people died. In conditions like this, everything is in a state of uncertainty, especially regarding when this pandemic will end. Basically Covid19 is a virus that is almost similar to SARS-CoV, and MERS-CoV with symptoms of the first case in Wuhan, China in the form of acute pneumonia (Rosyanti \& Hadi, 2020)

Anxiety is the most common mental disorder, affecting nearly 1 in 5 American adults (Kessler et al., 2005). Women are significantly more likely than men to develop an anxiety disorder throughout their lives (Angst \& Dobler-Mikola, 1985; Bruce et al., 2005; Regier et al., 1990). The National Comorbidity Survey (NCS) in 1990-1992 found that 


\section{The $1^{\text {st }}$ Conference On Public Health and Medical Sciences (ICOPHMEDS) 2021}

Vol. 1, No. 1, 79-85

the lifetime prevalence rate for each anxiety disorder was $30.5 \%$ for women and $19.2 \%$ for men (Kessler et al., 1994)

Prevalence rates were also higher in women than men for each of the anxiety disorders examined, including panic disorder, social anxiety disorder, generalized anxiety disorder (Kessler et al., 1994), and posttraumatic stress disorder (Kessler et al., 1995). In fact, according to the Epidemiological Catchment Area study, the estimated lifetime prevalence of anxiety disorders is also higher in women than men $(3.1 \% \mathrm{vs} .2 .0 \%$; Breslau et al., 2000).

It is likely that the level of anxiety between men and women will be different when almost the whole world is experiencing a Covid19 pandemic. Likewise, 4 months after Indonesia had the impact of the Covid19 pandemic, so it is necessary to conduct research on the differences in anxiety between men and women.

\section{Literature Review And Hypothesis Development}

Anxiety is a psychological response experienced by most people, especially during a pandemic. Anxiety is a psychological condition which is accompanied by symptoms of pressure, confusion, fear, and threats from outside (Andrian, 2017; Vibriyanti, 2020).

A pandemic has the meaning of an epidemic that is spreading simultaneously everywhere, covering a wide geographical area (Great Dictionary of the Indonesian Language, KBBI).

Formulation of the problem

Is there a difference in anxiety between men and women after 4 months of the covid19 pandemic in Lampung?

Aim

Knowing the difference in anxiety between men and women after 4 months of the covid19 pandemic in Lampung

Hypothesis

$\mathrm{Ha}=$ There is a difference in anxiety between men and women in 4 months after the covid19 pandemic in Lampung

Ho $=$ There is no difference in anxiety between men and women in 4 months after the covid19 pandemic in Lampung

\section{Research Methodology}

Quantitative research with a cross sectional approach. The population were all people aged $\geq 17$ years and residing in Lampung Province, obtained a sample of 102 respondents consisting of 31 men and 71 women by accidental sampling by filling out an online questionnaire. The analysis using independent sample t test with Mann Whitney NonParametric. This research was based on ethical approval number: 012004018 issued by the Universitas Ahmad Dahlan Ethics Commission, Yogyakarta.

The $1^{\text {st }}$ Conference On Public Health and Medical Sciences (ICOPHMEDS) 2021 


\section{The $1^{\text {st }}$ Conference On Public Health and \\ Medical Sciences (ICOPHMEDS) 2021}

2021

Vol. 1, No. 1, 79-85

4. Results And Discussions

Research result

1. Characteristics

\begin{tabular}{|c|c|c|}
\hline & Frequency & Percentage \\
\hline $\begin{array}{l}\text { Age (years): } \\
17-19 \\
20-29 \\
30-39 \\
40-49 \\
50-59 \\
\geq 60\end{array}$ & $\begin{array}{c}2 \\
30 \\
35 \\
24 \\
10 \\
1\end{array}$ & $\begin{array}{c}2 \\
29.4 \\
34.3 \\
23.5 \\
9.8 \\
1\end{array}$ \\
\hline \multicolumn{3}{|l|}{ Gender: } \\
\hline $\begin{array}{l}\text { Man } \\
\text { Woman }\end{array}$ & $\begin{array}{l}31 \\
71\end{array}$ & $\begin{array}{l}30.4 \\
69.6\end{array}$ \\
\hline $\begin{array}{l}\text { High School } \\
\text { College }\end{array}$ & $\begin{array}{l}10 \\
92\end{array}$ & $\begin{array}{c}9.8 \\
90.2\end{array}$ \\
\hline $\begin{array}{l}\text { Lecturer } \\
\text { IT } \\
\text { Civil Servant } \\
\text { Employee } \\
\text { Retired } \\
\text { Doctor } \\
\text { Housewife } \\
\text { Student } \\
\text { Health Promotion Staff } \\
\text { Consultant } \\
\text { Analyst } \\
\text { Nurse } \\
\text { Public Health Staff } \\
\text { Midwife } \\
\text { Not yet working } \\
\text { Environmental Health Staff }\end{array}$ & $\begin{array}{c}15 \\
1 \\
38 \\
7 \\
1 \\
6 \\
7 \\
12 \\
1 \\
1 \\
1 \\
3 \\
1 \\
6 \\
1 \\
1\end{array}$ & $\begin{array}{c}14.7 \\
1 \\
37.3 \\
6.9 \\
1 \\
5.9 \\
6.9 \\
11.8 \\
1 \\
1 \\
1 \\
2.9 \\
1 \\
5.9 \\
1 \\
1\end{array}$ \\
\hline \multicolumn{3}{|l|}{ Scope of Work: } \\
\hline $\begin{array}{l}\text { Outdoor } \\
\text { Indoor }\end{array}$ & $\begin{array}{l}18 \\
84 \\
\end{array}$ & $\begin{array}{l}17.6 \\
82.4 \\
\end{array}$ \\
\hline
\end{tabular}

The $1^{\text {st }}$ Conference On Public Health and Medical Sciences (ICOPHMEDS) 2021 


\section{The $1^{\text {st }}$ Conference On Public Health and Medical Sciences (ICOPHMEDS) 2021}

Vol. 1, No. 1, 79-85

Most respondents aged 30 - 39 years 35 people $(34.3 \%)$, with female sex 71 people (69.6\%), with a college education level 92 people $(90.2 \%)$, many of whom work as civil servants 38 people (37.3\%) and a lot of work indoors 84 people $(82.4 \%)$

2. Differences in anxiety between Men and Women after 4 Months of the Covid19 Pandemic

This data is not normally distributed where the value of sig $=0.000$ so that the analysis used to test the independent sample t test with Mann Whitney Non Parametric. The value of Asym sig ( 2 tailed $)=0.626$, which means $\mathrm{Ha}$ is rejected, there is no difference in anxiety between men and women in 4 months after the Covid19 pandemic in Lampung, with the anxiety elements are:

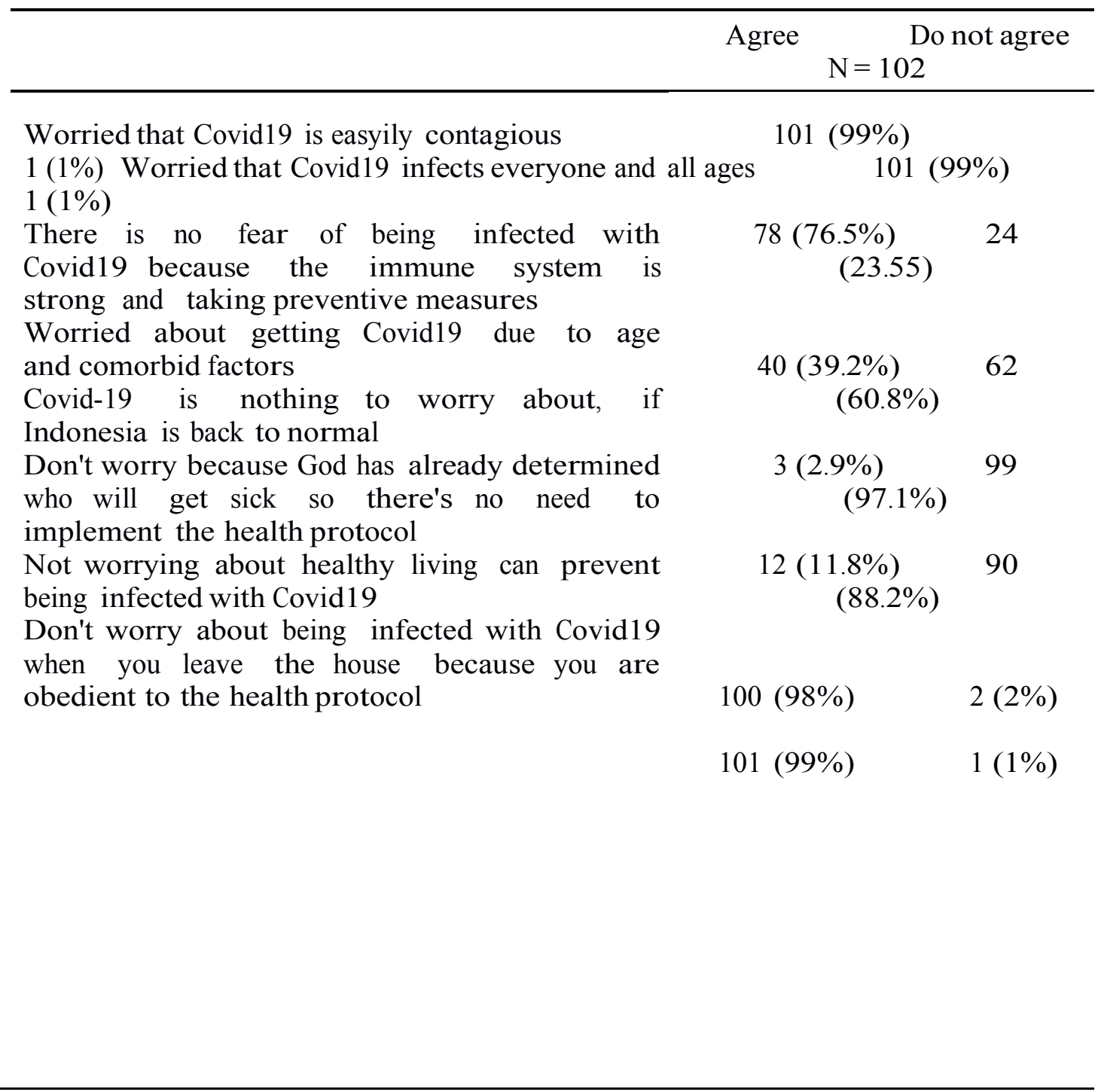

The $1{ }^{\text {st }}$ Conference On Public Health and Medical Sciences (ICOPHMEDS) 2021 


\section{The $1^{\text {st }}$ Conference On Public Health and Medical Sciences (ICOPHMEDS) 2021}

Vol. 1, No. 1, 79-85

\section{Discussion}

This research was conducted on 102 respondents who are in the Lampung area. Based on the results of the study, it was found that the age of most respondents was at the age of 30-39 years with a percentage of 39\% (35 people) and there was 1 person (1\%) with an age of more than 60 years. The research data obtained were male respondents as many as 71 people $(69.6 \%)$ and there were 31 women as many as $(30.4 \%)$.

The average anxiety score for women was 52.37 and the average anxiety score for men was 49.50. Based on the $t$ test analysis, it was found that the value of Asym sig ( 2 tailed) = 0.626 which means Ha is rejected, so there is no difference in anxiety between men and women in 4 months after the Covid19 pandemic in Lampung. This is in line with the research of Fahrianti, F., \& Nurmina, N. (2021), which is that there is no difference in anxiety in male and female students.

But contrary to the research of Papanastasiou \& Zembylas (2008) which found that men had lower levels of anxiety than women. According to Stuart and Laraia (2005), that women has a higher level of anxiety than men. This is in accordance with the theory that women are twice as likely to experience anxiety than men (Fortinesh, 2007). The result of this study is not in accordance with Supriyadi's research (2020) which found that female experienced more anxiety than male in dealing with Covid 19.

Anxiety is a psychological response experienced by most people, especially during a pandemic. Anxiety is a psychological condition which is accompanied by symptoms of pressure, confusion, fear, and threats from outside (Andrian, 2017; Vibriyanti, 2020). Covid 19 is a situation known as a pandemic. According to the Great Dictionary of the Indonesian Language (KBBI), a pandemic has meaning of an epidemic that spreads simultaneously everywhere, covering a wide geographic area (https://kbbi.web.id/pandemi).

The Covid-19 pandemic situation is one of the factor in the emergence of anxiety, namely the physical threat and the emergence of pain due to covid 19. It is known that one of the predisposing factors is gender, but in this study, there was no difference. The pandemic situation that has never been experienced by both men and women is one of the thing that illustrates during COVID-19 there is no difference in anxiety between men and women. Both men and women need the same adjustments in the face of the Covid-19 pandemic. In line with a survey conducted by the American Psychiatric Association (APA) on 1000 adults in the United States, it was found that $48 \%$ of the society are worried about being infected, $40 \%$ are worried about dying from the Covid 19 virus, $62 \%$ are worried about their loved ones and their families being affected by the Covid-19 virus. 19, 36\% said this virus had a serious impact on mental health, $59 \%$ said the effect was quite severe on daily life such as financial problems, food, medicine and others.

The results of this study are not in line with previous research which stated that women are easier to feel anxiety than men Wojciech R, et al (2009), it is not only because of

The $1{ }^{\text {st }}$ Conference On Public Health and Medical Sciences (ICOPHMEDS) 2021 


\author{
Vol. 1, No. 1, 79-85
}

gender that affects anxiety but many other factors that can affect anxiety. In addition, considering that this research was carried out during the Covid 19 pandemic where the problems that the community went through were so complex and almost all aspects were influenced, it made everyone both men and women feel the same anxiety and it was found that people experienced anxiety in the element of worrying about covid which is easily contagious. and infects people of all ages with a percentage of $99 \%$.

There are many other factors that make gender not a determinant in the level of anxiety facing COVID-19. The job factor, where the respondent dominates the workplace in the room as many as 84 people $(82.4 \%)$, makes men and women have the same anxiety. The average reproductive age at work also causes anxiety to have the same level between men and women. The respondent's job as a Civil Servant, allows the number of equal ratios between men and women, with a relatively equal workload. So that the anxiety they experienced in dealing with the COVID-19 pandemic is the same.

\title{
6. Conclusion
}

1. It is known that the majority of respondents are aged 30-39 years with a percentage of 39\% (35 people) and 1 person (1\%) with an age of more than 60 years.

2. It is known that there are 71 male respondents $(69.6 \%)$ and 31 female respondents $(30.4 \%)$

3. The average anxiety score for women is 52.37 and the average anxiety score for men is 49.50

4. There is no difference in anxiety between men and women in 4 months after the Covid19 pandemic in Lampung because the value of Asym sig ( 2 tailed $)=0.626$

\section{Suggestion}

1. Theoretical

1.1. Become a material for further research on anxiety, especially during the Covid-19 pandemic

1.2. Become a material so that further research can add variables and characteristic data to reduce bias in research

1.3. Enriching scientific knowledges, especially in anxiety that the Covid-19 pandemic condition is able to change a person's state of anxiety if it is outside the Covid-19 pandemic.

2. Applicable

2.1. Consultation and handling related to anxiety facing Covid-19, can be equated between men and women.

\section{Limitation And Study Forward}

1. Measuring tools using online questionnaires

2. The number of respondents does not represent the proportion of the population of Lampung 


\section{The $1^{\text {st }}$ Conference On Public Health and \\ Medical Sciences (ICOPHMEDS) 2021}

Vol. 1, No. 1, 79-85

\section{Acknowledgement}

The author greatfully acknowledge the financial support from the Institute for Research Institute and Community Service (LPPM) Universitas Malahayati, Lampung, Indonesia

\section{References}

Fahrianti, F., \& Nurmina, N. (2021). Differences in New Student Anxiety in terms of Gender during the Covid-19 Pandemic Journal of Education Tambusai, 5(1), 1297-1302.

McLean, C. P., Asnaani, A., Litz, B. T., \& Hofmann, S. G. (2011). Gender differences in anxiety disorders: prevalence, course of illness, comorbidity and burden of illness. Journal of psychiatric research, 45(8), 1027-1035.

Papanastasiou, EC, \& Zembylas, M. (2008). Anxiety in undergraduate research methods courses: its nature and implications. International Journal of Research \& Methods in Education, 31(2), 155-16

Sitohang, TRS, Rosyad, YS, \& Rias, YA (2021). ANALYSIS OF ANXIETY FACTORS IN THE WEST OF INDONESIA COMMUNITY DURING THE COVID PANDEMIC 19 YEAR 2020. Journal of Endurance: Scientific Study of Health Problems, 6(2), 279-289.

Supriyadi (2020). The Effect of Health Education on Covid-19 Prevention on Community

Anxiety in Yogyakata. Journal of Nursing Volume 12no 4, Pages 767-776, December2020

Stuart, GW, \& Laraia, MT (2005). Psychiatric nursing. St. Louis: Mosby, 270271. 